\title{
On soil genesis in temperate humid climate. VII The formation of a glossaqualf in a silt-loam terrace deposit
}

\author{
J. Bouma and J. van Schuylenborgh \\ Laboratory of Regional Soil Science, Agricultural University, Wageningen, \\ the Netherlands
}

Received 20 March 1969

\section{Summary}

A poorly drained soil profile, developed in soliflucted clayey terrace deposits with a thin cover of loess, was characterized by physical, chemical and morphological methods. The B-horizon is considered to be of Pleistocene age. Clay skins on peds were absent in the B. In thin sections, however, oriented clay was observed inside peds occurring undisturbed as free grain and channel argillans, and disturbed by pedoturbation as quasicutans and papules.

Clay was leached vertically through the B along planar voids between prisms, leaving accumulations of skeleton grains (skeletans). The albic horizon therefore tongues into the argillic horizon. Some movement of clay into the prisms was also observed. From the present $A_{2}$, a thin sediment of loess on top of a truncated relict profile, some clay was leached as well.

Kaolinite proved to be more mobile than illite and smectite.

Processes of reduction resulted in strongly bleached areas around prisms. Inside the prisms and in smaller peds some reduction also occurred, as was indicated by well developed mangans on ped faces and around channels.

The classification as an Aeric Glossaqualf was based on the analytical data.

\section{Introduction}

A poorly drained soil profile in a quarry near Simpelveld (Limburg, the Netherlands) was found in a relatively elevated position. It was developed in a clayey parent material, covered by a thin layer of loess. A study of a cross section of the soils in the quarry (Fig. 1) combined with X-ray studies of the clay separates of the horizons have revealed the following facts.

The bottom of the soil is formed by terrace deposits, partly sandy (6) and partly clayey (5). On top of this terrace clayey materials are deposited by solifluction processes, with a stoneline as boundary between both sediments. In the terrace, locally well stratified, a dark horizontal band (7) was present which was high in organic matter. The sandy terrace showed well developed phenomena of frost action in its upper part. The lower solifluction layer (4), present over the whole section and cutting the dark band, contains stones, partly as a stoneline at its upper boundary. Its clay content 


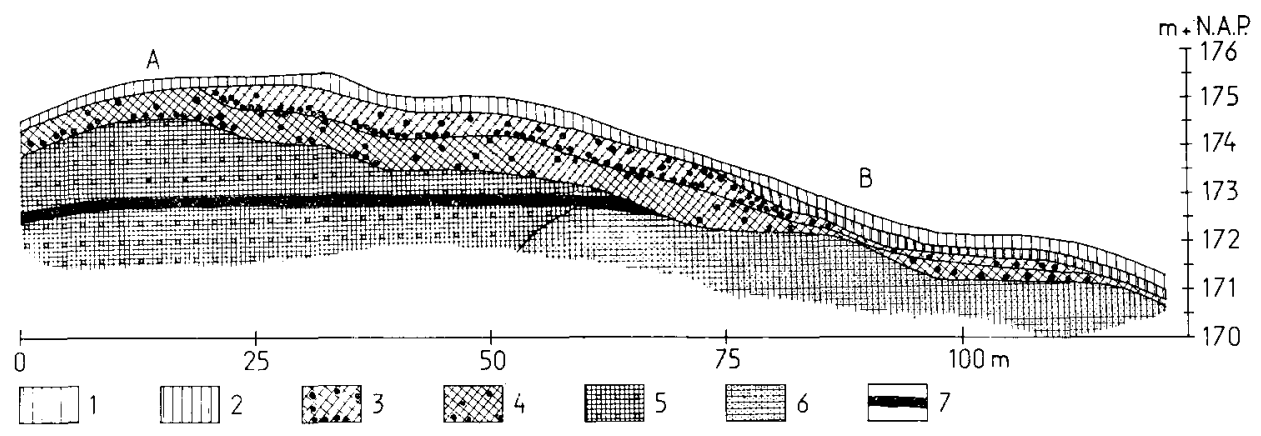

Fig. I Cross-section of soil profiles in a quarry near Simpelveld (Limburg, the Netherlands). For explanation of numbers, see text, p. 262

is about $30 \%$. Both materials (terrace and lower solifluction layer) have similar clay compositions, being predominantly smectite, with minor admixtures of kaolinite and mica. The upper solifluction layer (3) contains less clay, whereas its clay composition was predominantly mica, kaolinite, and chlorite with a small admixture of smectite. Layer (2), only present in the lower part of the section, was separated from (3) by a stoneline. It did not contain any stones itself. Its texture was that of an argillic horizon developed in a thick loess (silt-loam) sediment. No smectite was observed, chlorite, mica and kaolinite were dominant. Well developed polygons could be observed in horizontal sections (on site B, Fig. 1). All this was covered by about $30 \mathrm{~cm}$ of loess without stones, abruptly separated from the underlying layers. On some places some small stones were found at the base of layer (1), indicating an erosion stage with solifluction previous to the deposition of layer (1). The clay mineralogy of the loess was comparable to that of layer (2). However, the content of mica was considerably lower. Apparently, processes of solifluction played a dominant part in the genesis of the landscape. First a layer dominantly composed of terrace clay (4) was moved, later to be followed by material of mixed origin, containing some loess as well (3). Undisturbed loess was sedimented on top of that, only on the lower part of the slope (2), to be followed later, after soil formation and probably erosion, by a thin cover of loess over the whole area (1).

The profile investigated (Site A, Fig. 1) was developed in three parent materials: Nos 1, 4 and 5 . Its morphology and probable genesis will be discussed.

\section{Profile description}

\section{General data}

Location: Topographical map of the Netherlands, Sheet 62B: Heerlen. $196.50 \mathrm{O}-$ $313.49 \mathrm{~N}$; a poor forest with Betula sp. is found at the site; the geological outline is given in 'Introduction'; concave relief; slope $3 \% \mathrm{SE}$; altitude NAP $1+172.5 \mathrm{~m}$. The profile is poorly drained; roots are concentrated in the upper part of the profile and in cracks along prisms. No worm burrows. Climatical data are given in Table 1.

1 NAP, the New Amsterdam Level, is the Netherlands standard for altitudes. 
ON SOIL GENESIS IN TEMPERATE HUMID CLIMATE. VII

Table 1 Climatical data (average values) for the period 1930-1960

\begin{tabular}{lccccc}
\hline & Winter & Spring & Summer & Autumn & Total \\
$\begin{array}{l}\text { Precipitation (mm) } \\
\begin{array}{l}\text { Evaporation from a free } \\
\text { water surface (mm) }\end{array}\end{array}$ l60 & 32 & 148 & 198 & 188 & 694 \\
\hline
\end{tabular}

\section{Description of the profile}

$\mathrm{O}_{2} \quad 3-0 \quad \mathrm{~cm}$ black (5YR 2/1), highly humified, weakly shining organic material with a plastic consistency; abrupt smooth boundary.

A $20-13 \mathrm{~cm}$ silt; (10YR 6/1) moist; massive structure with common very fine biopores; firm; many fine prominent Fe mottles (5YR 5/8) dominantly as channel-neoferrans with sharp boundaries along very fine biopores; along boundary between $A_{2}$ and $B_{t_{g}}$ is a concentration of stones; gradual smooth boundary.

II $\mathrm{B}_{1 \mathrm{~g}} \quad 13-35 \mathrm{~cm}$ silt-loam; $2.5 \mathrm{Y} 6 / 2$ and $7.5 \mathrm{YR} 5 / 8$ (each about $50 \%$ of the total volume); moist; weak coarse prismatic structure with common very fine biopores on ped faces and in peds; firm, locally friable; few fine distinct black Mn mottles on ped faces; gradual wavy boundary.

II $\mathrm{B}_{2 \mathrm{tg}} \quad 35-110 \mathrm{~cm}$ silt-loam; $5 \mathrm{GY} 0 / 6$ along prisms and $5 \mathrm{YR} 4 / 6$ within the prisms; locally lighter spots are found in $20 \%$ of volume $(2.5 \mathrm{Y} 6 / 2)$ inside the prisms; moist; in upper part of the horizon $(35-70 \mathrm{~cm})$ moderate coarse smooth prismatic breaking to moderate fine prismatic structure; in the lower part coarse and very coarse smooth prismatic, breaking to moderate medium prismatic structure; 10cally segmentation of the prisms along horizontal planes; on faces of peds very few or no very fine biopores; inside peds common to many very fine biopores; faces of the coarse prisms covered with accumulations of silt particles up to about $1 \mathrm{~mm}$ thick (skeletans), with locally concentrations; firm to very firm; many fine and medium prominent $\mathrm{Mn}$ mottles inside the prisms around channels, surrounded by a band of red (5YR 4/6) Fe mottles; Mn coatings are also found on horizontal ped faces; gradual smooth boundary.

III $\mathrm{C}_{\mathrm{g}}>110 \mathrm{~cm}$ silt-loam; upper band contains many fine stones, dominantly quartz and chert; 5 GY $0 / 6$; very moist; massive structure with few very fine biopores; slightly plastic; non-sticky; in some layers about $10 \mathrm{~cm}$ thick are common fine prominent Mn spots.

Biopores very fine $(1 \mathrm{~mm})$; few: $<5$ per $\mathrm{cm}^{2}$; common: $5-10$ per $\mathrm{cm}^{2}$; many: $10-15$ per $\mathrm{cm}^{2}$.

\section{Methods and materials}

The methods used have been reported in a previous paper (Bouma et al., 1968). Of the $\mathrm{B}_{2 \mathrm{tg}}$ horizons bleached soil parts occurring around prisms and brown soil inside the prisms were analysed separately. An analysis of a representative mixed sample was also prepared. Of the $\mathbf{B}_{1 \mathrm{~g}}$ horizon, where the brown parts were to much scattered to allow sampling, only a mixed sample and one composed of bleached material was analysed. Furthermore the $\mathrm{A}_{2 \mathrm{~g}}$ and $\mathrm{C}_{\mathrm{g}}$ horizons were sampled and analyzed.

\section{Physical, chemical, and geochemical characteristics}

In Table 2 the general characteristics of the profile have been listed. The $\mathrm{pH}$ values and the $\mathrm{C}$ contents are low. The granulometric composition of the bleached part of the $B_{1 g}$ horizon approaches that of the $A_{2 g}$. The bleached parts of the $B_{2 g}$ horizons have a lower clay content than the brown parts. 
The cation exchange characteristics (Table 3) show that the profile has a low base saturation, that is, however, still higher than $35 \%$, the upper limit for Ultisols.

About $15 \%$ of the exchange complex is occupied by Na. This is a relatively high value.

Table 2 General characteristics of the profile

\begin{tabular}{|c|c|c|c|c|c|c|c|c|c|c|}
\hline & \multirow[t]{2}{*}{$A_{2 g}$} & \multicolumn{2}{|c|}{$\boldsymbol{B}_{\boldsymbol{I g}}$} & \multicolumn{3}{|c|}{$B_{* 1 t g}$} & \multicolumn{3}{|c|}{$B_{22: t g}$} & \multirow[t]{2}{*}{$C_{g}$} \\
\hline & & $a v$ & bl.p. & $a v$. & bl.p. & br.p. & $a v$ & bl.p. & br.p. & \\
\hline$>50 \mu \mathrm{m}(\%){ }^{\prime}$ & 6.7 & 6.1 & 6.6 & 8.0 & 8.2 & 7.4 & 13.8 & 12.8 & 13.3 & 15.2 \\
\hline $50-2 . \mathrm{mm}(\%)$ & 82.6 & 74.5 & 80.2 & 87.5 & 68.8 & 63.8 & 57.3 & 60.7 & 56.3 & 55.8 \\
\hline$<2 u \mathrm{~m}(\%)$ & 10.7 & 19.4 & 13.2 & 24.5 & 23.0 & 28.8 & 29.0 & 26.5 & 30.4 & 29.0 \\
\hline $\mathrm{pH}\left(\mathrm{H}_{2} \mathrm{O}\right)$ & 4.4 & 4.3 & 4.5 & 4.4 & 4.5 & 4.4 & 4.7 & 4.6 & 4.5 & 4.9 \\
\hline $\mathrm{pH}(0.01 \mathrm{M} \mathrm{CaCl})$ & 3.9 & 3.6 & 3.7 & 3.7 & 3.8 & 3.7 & 3.8 & 3.8 & 3.7 & 3.9 \\
\hline $\mathrm{C}(\%)$ & 1.7 & 0.2 & 0.1 & 0.2 & 0.1 & 0.2 & 0.1 & 0.1 & 0.1 & 0.1 \\
\hline
\end{tabular}

1 Percentages of earth fine fraction; av. = average composition of the horizon; bl.p. = bleached part; br.p. $=$ = brown part.

Table 3 Cation-exchange capacity (CEC) of some horizons (meq/100 g of soil)

\begin{tabular}{|c|c|c|c|c|c|c|c|}
\hline \multirow[t]{2}{*}{ Horizon } & \multicolumn{5}{|c|}{ Exchangeable cations } & \multirow[t]{2}{*}{$C E C$} & \multirow{2}{*}{$\begin{array}{c}\text { Base } \\
\text { saturation } \\
\text { (\%) }\end{array}$} \\
\hline & $\mathrm{Ca}$ & $M g$ & $K$ & $\mathrm{Na}$ & $A l+H$ & & \\
\hline $\mathbf{B}_{21 \mathrm{tg}}$ & 3.2 & 1.2 & 0.1 & 2.1 & 8.2 & 14.8 & 45 \\
\hline $\mathrm{C}_{\mathrm{g}}$ & 6.7 & 2.7 & 0.1 & 2.0 & 1.4 & 12.9 & 89 \\
\hline
\end{tabular}

Table 4 Geochemical data of the profile (weight percentages) and derived molar ratios

\begin{tabular}{|c|c|c|c|c|c|c|c|c|c|c|}
\hline & \multirow[t]{2}{*}{$A_{g_{g}}$} & \multicolumn{2}{|c|}{$B_{1 g}$} & \multicolumn{3}{|c|}{$B_{21 / g}$} & \multicolumn{3}{|c|}{$B=2 / g$} & \multirow[t]{2}{*}{$C_{g}$} \\
\hline & & $a v$. & bl.p. & $a v$ & bl.p. & br.p. & $a v$ & bl.p. & $b r . p$. & \\
\hline $\mathrm{SiO}_{2}$ & 85.3 & 79.6 & 82.4 & 76.3 & 76.6 & 72.7 & 74.4 & 78.4 & 73.2 & 78.8 \\
\hline $\mathrm{Al}_{2} \mathrm{O}_{3}$ & 6.4 & 8.8 & 7.5 & 10.7 & 10.5 & 11.2 & 9.5 & 9.8 & 9.9 & 9.4 \\
\hline $\mathrm{Fe}_{2} \mathrm{O}_{3}$ & 1.7 & 3.9 & 1.9 & 4.4 & 3.1 & 6.6 & 5.7 & 3.0 & 7.1 & 2.9 \\
\hline $\mathrm{FeO}$ & 0.2 & 0.1 & 0.1 & 0.1 & 0.1 & 0.1 & $\operatorname{tr}$ & $\operatorname{tr}$ & $\mathrm{tr}$ & $\operatorname{tr}$ \\
\hline $\mathrm{MnO}$ & 0.05 & 0.05 & $\operatorname{tr}$ & 0.05 & $\operatorname{tr}$ & 0.2 & 0.1 & $\operatorname{tr}$ & 0.2 & $\operatorname{tr}$ \\
\hline $\mathrm{CaO}$ & 0.4 & 0.3 & 0.3 & 0.3 & 0.1 & 0.3 & 0.2 & 0.2 & 0.2 & 0.3 \\
\hline $\mathrm{MgO}$ & 0.2 & 0.4 & 0.3 & 0.4 & 0.4 & 0.4 & 0.4 & 0.4 & 0.4 & 0.4 \\
\hline $\mathrm{Na}_{2} \mathrm{O}$ & 1.1 & 1.1 & 1.0 & 0.6 & 0.6 & 0.5 & 0.3 & 0.4 & 0.3 & 0.3 \\
\hline $\mathrm{K}_{2} \mathrm{O}$ & 1.5 & 1.7 & 1.7 & 1.6 & 1.6 & 1.6 & 1.5 & 1.7 & 1.5 & 1.7 \\
\hline $\mathrm{TiO}_{2}$ & 0.7 & 0.7 & 0.8 & 0.7 & 0.7 & 0.7 & 0.7 & 0.8 & 0.7 & 0.8 \\
\hline $\mathrm{P}_{2} \mathrm{O}_{5}$ & 0.1 & 0.1 & $\operatorname{tr}$ & 0.1 & 0.1 & 0.1 & 0.1 & 0.05 & 0.1 & $\mathrm{tr}$ \\
\hline $\mathrm{H}_{2} \mathrm{O}^{-}$ & 3.7 & 2.8 & 2.1 & 3.3 & 3.0 & 3.7 & 3.9 & 3.6 & 4.4 & 3.4 \\
\hline free $\mathrm{Fe}_{2} \mathrm{O}_{3}$ & 1.1 & 1.3 & 0.7 & 1.5 & 1.3 & 1.6 & 1.1 & 0.9 & 1.3 & 1.2 \\
\hline $\mathrm{SiO}_{2} / \mathrm{R}_{2} \mathrm{O}_{3}$ & 19 & 12 & 16 & 9.6 & 11 & 8.0 & 9.8 & 12 & 8.7 & 12 \\
\hline $\mathrm{SiO}_{2} / \mathrm{Al}_{2} \mathrm{O}_{3}$ & 23 & 16 & 19 & 12 & 12 & 11 & 13 & 14 & 13 & 14 \\
\hline $\mathrm{SiO}_{2} / \mathrm{Fe}_{2} \mathrm{O}_{3}$ & 123 & 55 & 128 & 46 & 65 & 29 & 37 & 75 & 29 & 78 \\
\hline $\mathrm{Al}_{2} \mathrm{O}_{3} / \mathrm{Fe}_{2} \mathrm{O}_{3}$ & 5.4 & 3.6 & 6.9 & 3.7 & 5.2 & 2.6 & 2.8 & 5.6 & 2.3 & 5.5 \\
\hline
\end{tabular}

av. = average $;$ bl.p. = bleached part $;$ br.p. = brown part. 
ON SOIL GENESIS IN TEMPERATE HUMID CLIMATE. VII

Table 5 Normative mineralogical composition of the profile (equivalent percentages)

\begin{tabular}{lcrrrrrrrr}
\hline Hor. & $Q$ & Or & $A b$ & Kaol & Ms & Sm & Chl & Go & Misc \\
$\mathrm{A}_{2 \mathrm{~g}}$ & 74.0 & 0.7 & 8.0 & - & 13.0 & - & 1.3 & 1.3 & 1.4 \\
$\mathrm{~B}_{\mathrm{:g}}$ & 65.7 & - & 10.7 & 1.0 & 15.2 & 2.6 & 0.2 & 3.0 & 1.5 \\
$\mathrm{~B}_{21 \mathrm{tg}}$ & 61.6 & - & 5.8 & 6.9 & 15.0 & 5.6 & - & 3.4 & 1.7 \\
$\mathrm{~B}_{22 \mathrm{~g}}$ & 65.0 & - & 3.2 & 6.6 & 14.3 & 5.0 & - & 4.5 & 1.4 \\
$\mathrm{C}_{\mathrm{g}}$ & 67.8 & - & 3.2 & 4.3 & 15.8 & 5.0 & - & 2.3 & 1.8 \\
\hline
\end{tabular}

$\mathrm{Q}=$ silica $; \mathrm{Or}=\mathrm{K}$-feldspar $; \mathrm{Ab}=$ albite $; \mathrm{Kaol}=$ kaolinite $\mathrm{Ms}=$ muscovite (illite) $\mathrm{Sm}=$ smectite $; \mathrm{Chl}=$ chlorite $:$ Go $=$ goethite $;$ Misc $=$ miscellaneous.

It may result from the presence of albite in the non-clay fraction (Table 5).

Further chemical characteristics are given in Table 4 , that may be summarized as follows :

1. With depth decreasing $\mathrm{SiO}_{2} / \mathrm{Al}_{2} \mathrm{O}_{3}$ ratio which points either to clay migration or to destruction of clay in the upper part of the profile, followed by leaching of liberated alumina.

2. Decreasing $\mathrm{Al}_{2} \mathrm{O}_{3} / \mathrm{Fe}_{2} \mathrm{O}_{3}$ ratio, which means that iron is more mobile than alumina.

3. The bleached parts of the horizons are poorer in manganese and iron than the brown parts.

4. The bleached parts of the horizons are poorer in alumina and richer in silica than the brown parts.

The characteristics described as 2 and 3 have been discussed previously (Bouma et al., 1967). A discussion of points 1 and 4 is more difficult. For this a total mineralogical analysis of all horizons should be available. As exact quantitative analyses of this type are extremely difficult, if possible at all, other have been developed to calculate the mineralogical composition from chemical data. Niggli (see Burri, 1964) describes such a method for igneous, sedimentary and metamorphic rocks. A comparable method, the goethite-norm calculation for soils, has been worked out recently (van der Plas and van Schuylenborgh, 1970). The results, checked by X-raying as far as possible, of such a calculation are given in Table 5 .

From this data it is clear that the $\mathbf{A}_{2 g}$ horizon has developed in soil material that is different from the rest of the solum. Furthermore, an increase in kaolinite and smectite from the $\mathbf{B}_{\mathbf{1}_{\mathrm{g}}}$ to the $\mathbf{B}_{\mathbf{2}_{\mathrm{tg}}}$ and a decrease in albite and silica can be observed.

Finally also calculations have been made for the bleached and brown parts of horizons $\mathbf{B}_{1 \mathrm{~g}}$ and $\mathbf{B}_{21 \mathrm{gg}}$ (Table 6). This reveals that the content of kaolinite is lower in the bleached part of each horizon as compared with the average composition in the $\mathrm{B}_{1 \mathrm{~g}}$ and with that of the brown parts in the $B_{21 \mathrm{~g}}$.

\section{Micromorphological characteristics}

A detailed, though schematic description according to Brewer (1964) shows the following features.

$\mathrm{O}_{2} \quad$ Between few isolated skeleton grains :

a. very fine $(30-60, u \mathrm{~m})$ opaque irregular organic fragments with sharp boundaries;

b. brown irregularly rounded excrements $(50-100 \mu \mathrm{m})$, locally disturbed, with many very fine opaque fragments and few plant remains with cellulose;

c. many hyphes and spores of fungi ;

d. many recognizable round root fragments, the inner part of which has been decomposed, the outer part is opaque. 
Table 6 Normative mineralogical composition of different parts of horizons $B_{1_{g}}$ and $B_{2 t_{\mathrm{g}}}$ (equivalent percentages)

\begin{tabular}{lrrrrrrrrr}
\hline Hor. & $Q$ & $A b$ & Kaol & $M s$ & $S m$ & Go & Pyro & Misc & Total \\
B & & & & & & & & & \\
bl.p. & 70.0 & 9.8 & - & 15.4 & 2.0 & 1.6 & - & 1.3 & 100.0 \\
same 1 & 72.1 & 10.1 & - & 15.8 & 2.0 & - & - & - & 100.0 \\
B $_{1 \mathrm{~g}}$ & 65.7 & 10.7 & 1.0 & 15.2 & 2.6 & 3.0 & - & 1.5 & 99.7 \\
same 1 & 69.0 & 11.2 & 1.0 & 16.0 & 2.8 & - & - & - & 100.0 \\
B $_{21 \mathrm{tg}}$ & & & & & & & & & \\
bl.p. & 63.2 & 6.0 & 6.7 & 15.0 & 5.6 & 2.4 & - & 1.1 & 100.0 \\
same 1 & 65.6 & 6.2 & 6.9 & 15.6 & 5.7 & - & - & - & 100.0 \\
B21tg & & & & & & & & & \\
br.p. & 58.8 & 5.0 & 8.4 & 15.0 & 5.6 & 5.1 & 0.2 & 1.9 & 100.0 \\
same 1 & 63.4 & 5.4 & 9.1 & 16.2 & 6.0 & - & - & - & 100.0 \\
\hline
\end{tabular}

Mineral abbrevations as in Table 5; Pyro = pyrolusite; bl.p. = bleached part ; br.p. = brown part.

1 Calculated to the sum of 100 of silicate minerals.

A Plasma as $\mathrm{O}_{2}$, but with much lower content of opaque organic remains.

$\mathrm{A}_{2 \mathrm{~g}}$ Silasepic plasmic fabric; vughy porphyroskelic s-matrix with common very coarse equant $\mathrm{Fe}-$ Mn nodules with recognizable soil fabric and a sharp boundary, containing many free grain ferri-argillans and papules in the s-matrix; in about $20 \%$ of the volume and distributed in irregular patterns, are very fine yellow illuviation free grain ferri-argillans with strong continuous orientation.

$\mathbf{B}_{2 \mathrm{tg}}$ Bleached, grey areas around prisms; silasepic plasmic fabric; channelled porphyroskelic s. matrix with:

a. many very fine white illuviation free grain argillans with strong continuous orientation;

b. few fine white illuviation channel argillans with a moderate to strong continuous orientation, often in striated patterns; also quasiargillans are found with a similar fabric.

The amount of channel argillans increases with increasing depth. Interpedal pedological feature: common well developed eluvation skeletans, locally in pockets.

Inside prisms two separate microfabrics have to be distinguished:

1. silasepic plasmic fabric; channelled porphyroskelic s-matrix with:

a. many very fine light yellow illuviation free grain argillans with strong continuous orientation;

b. fine and medium channel and ped diffusion neo-mangans-ferrans with rather sharp boundaries ;

2. silasepic plasmic fabric (dominant fabric); channelled porphyroskelic s-matrix with:

a. mane very fine yellow illuviation free grain argillans with strong continuous orientation;

b. common fine yellow illuviation channel ferri-argillans with a moderate to strong continuous orientation, often somewhat striated, also quasiargillans are found with a similar fabric;

c. few fine yellow papules with a moderate continuous orientation;

d. few fine compound illuviation channel argillans, the lower part of which is composed of a fine yellow or red ferri-argillan (or sometimes a ferran), the upper part of a fine white argillan.

Remark: the $B_{1}$ horizon is intermediate in properties between the $A_{2 g}$ and $B_{2 t g}$ horizon.

Humification in the $\mathrm{O}_{2}$ horizon, governed by fungi, is poor. In the $\mathrm{A}_{2} \mathrm{Fe}-\mathrm{Mn}$ nodules had a higher content of papules and free grain argillans than the surrounding soil material. In the $B_{2 \text { tg }}$ the content of oriented clay was lower in the bleached parts, around prisms, than in the brown parts inside. Argillans were not found on faces of prisms. Here accumulations of skeleton grains (skeletans) formed the dominant feature.

Inside the prisms, locally slightly bleached parts were observed. Here neomangans were common around channels, with accumulation of iron at a somewhat larger distance from the void.

In the brown parts, inside prisms, white illuviation argillans were found. 


\section{Discussion}

The formation of the argillic horizon

From the calculated normative mineralogical composition, it is concluded that the $\mathbf{A}_{\mathbf{2}_{\mathrm{g}}}$ horizon has been developed in a soil material that is different from the material of the underlying B. Clay-mineralogical analyses confirmed this conclusion: Clay minerals, present in the thin cover of loess in which an $\mathrm{A}_{\mathbf{2 g}}$ horizon has developed, were dominantly of the chlorite-illite type. The $\mathrm{B}_{2 \mathrm{tg}}$, on the contrary has a considerable content of smectite. A third indication was formed by the occurrence of a concentration of stones between the $A_{2 g}$ and $B_{1}$ horizon, indicating a certain stage of solifluction when this level was exposed to the surface. In view of this evidence it is not warranted to consider the profile as a sequum (Soil Survey Staff, 1960) developed in a homogeneous parent material. Furthermore it is not very likely that all oriented clay observed in thin sections of the $\mathbf{B}$ was eluviated from the present $\mathbf{A}_{2}$. In view of this, the $\mathrm{B}$ may be considered to belong to a truncated profile, later covered by a younger sediment. Since this is loess here, the underlying profile could be of pleistocene age, as has been stated before (Hoeksema and Edelman, 1960; Janekovic, 1961; Gile and Grossman, 1968). However, there has been a lateral movement and deposition of clay in the B horizon itself as is shown by the occurrence of strongly oriented white channel argillans in the interior of prisms (Fig. 2). This clay apparently was removed from the bleached parts along the faces of prisms. After deposition it contributes to the amount of oriented clay in the B horizon, although it was not eluviated from the $\mathrm{A}_{2}$ (see also McCaleb, 1959).

Apart from this lateral movement in the horizon itself, also a pronounced vertical movement of clay occurred, as is evidenced by the presence of well developed skeletans on the vertical faces of the prisms. The skeletans have been formed after removal of clay by eluviation. Ped argillans therefore are not found. Only channel and free grain argillans and disturbed argillans, present as papules or quasicutans, were observed in thin section. These disrupted orthic pedological features were formed by processes of pedotturbation (Hole, 1961). Some clay has been eluviated from the present $\mathbf{A}_{2 g}$, however, as is indicated by the occurrence of concentrations of oriented clay in irregular patterns notably in large Fe-Mn nodules. Here a certain s-matrix of an earlier state of development, with oriented clay, has been fixed.

The calculation of the normative mineralogical composition (Table 5) reveals a strong increase in kaolinite from the $\mathbf{B}_{1 \mathrm{~g}}$ to the $\mathbf{B}_{2 \mathrm{tg}}$. This could indicate a preferential movement during leaching. As we found that kaolinite was more mobile than illite or monmorillonite in many profiles of the R.Y. Podzolic and Mediterranean soil groups, we think that this is a general phenomenon. It is also in agreement with the results of experiments of Hallsworth (1963). This greater mobility of kaolinite can well be observed by comparing the composition of the bleached and brown parts of the horizons. This is done for horizons $\mathbf{B}_{1 \mathrm{~g}}$ and $\mathbf{B}_{21 \mathrm{tg}}$.

If the bleached parts are the strongest leached parts of the horizons, the kaolinite content of these parts should be lower than that of the brown parts, whereas the illite and smectite should not vary much. This appears to be true as is shown in Table 6 . The kaolinite content of the bleached part of the $B_{1 g}$ is zero, and of the whole soil $1.0 \%$. The brown part of the horizon, that was not separately sampled, will therefore have a much higher content than $1 \%$. The kaolinite content of the bleached part of $B_{21}$ ig considerably lower than that of the brown part, whereas those for illite and 

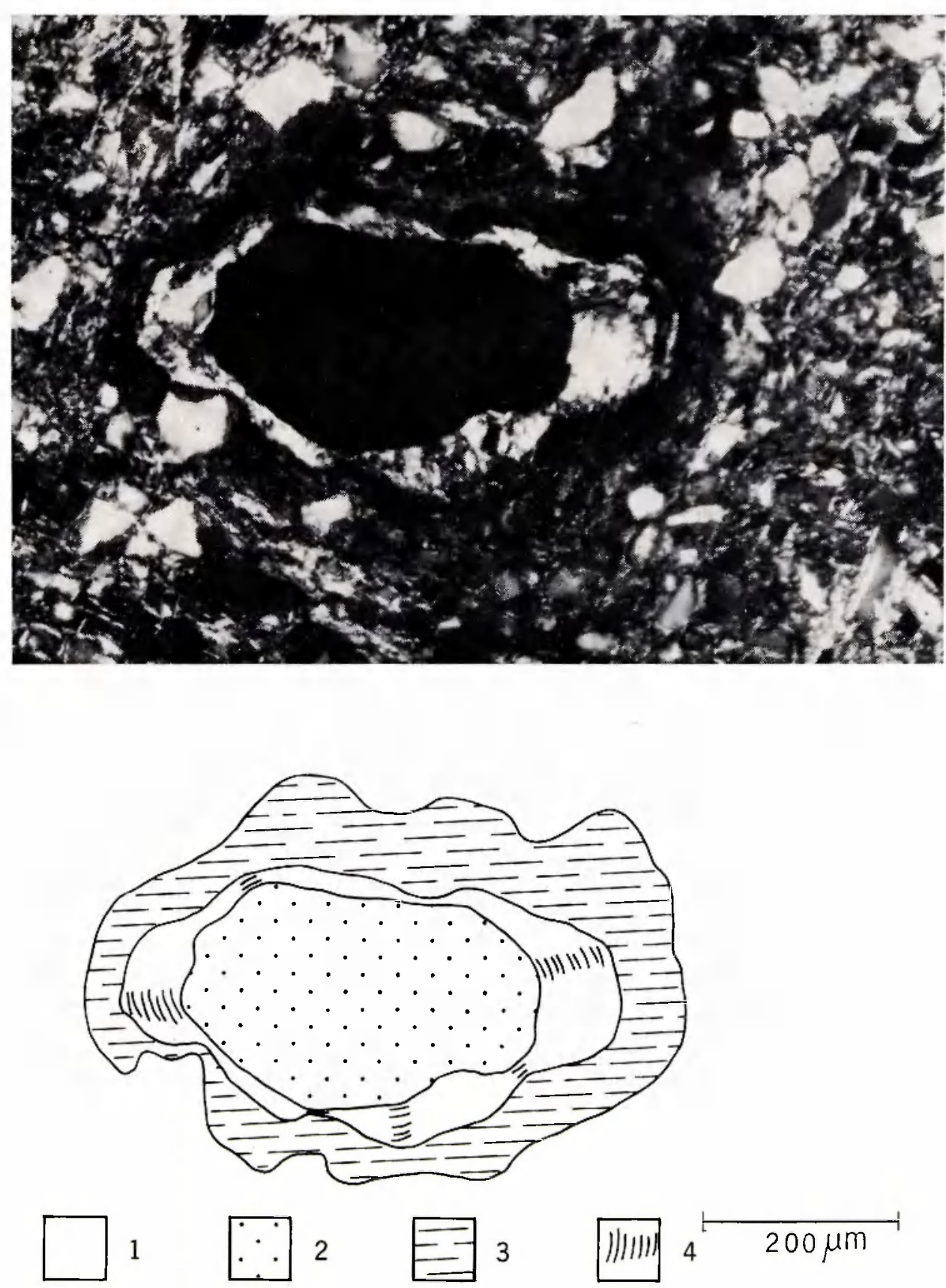

Fig. 2 A white illuviation channel argillan found in the interior of a prism in the $B_{y_{\mathrm{tg}}}$ (picture with crossed polarizers). $I=s$-matrix $; 2=$ chamel $; 3=$ red illuviation channel ferri-argillan $; 4=$ white illuviation channel argillan, with clear extinction bands 
smectite show only slight differences.

Profile development implies a penetration of the $A_{2}$ into the upper parts of the $B_{2 t}$ horizon, a development that is most pronounced along water conducting voids between prisms (Bouma et al., 1968). As a result the clay content of these bleached parts is lower than that of the rest of the horizon at the same depth (Table 2). This phenomenon has also been described by Jha and Cline for fragipans (1963).

The differences in clay content are not as pronounced as in the Glossudalf (Bouma et al., 1968). This is due to the more clayey texture of the parent material here, that results in a lower permeability and in poor drainage. Leaching therefore is less pronounced.

\section{The occurrence of gley phenomena}

The morphology of the $B_{2 t g}$ seems to indicate the occurrence of processes as found in pseudo-gley profiles (Bouma et al., 1968). The prisms are surrounded by a bleached grey zone and roots are found mainly on faces of prisms. The interior of the prisms, however, has a flecked appearance with grey bleached parts containing iron and manganese mottles next to brown soil with mottles. In the aequic glossudalf (Bouma et al., 1968) the interior of the prisms was homogeneously brown with some manganese mottles. A clear iron band was found bordering the bleached tongues along vertical ped faces. This indicated the presence of a weakly developed pseudogley profile in a relatively permeable soil material (Blume, 1968). In the profile under discussion processes of reduction apparently occur inside the prisms as well, as a result of a local saturation with moisture in presence of organic matter.

Micromorphologic observations reveal that oxidation of the reduced compounds occur along larger voids inside the prisms, notably along channels. In the neocutans formed in this way, manganese has been oxidized immediately along the channels, whereas oxidized iron compounds are found at somewhat larger distances from the void (Fig. 3). A discussion of redox potentials (Bouma et al., 1968) revealed that the oxidation of a reduced solution containing $\mathrm{Fe}^{2+}$ and $\mathrm{Mn}^{2+}$ ions, leads to precipitation of $\mathrm{Fe}$ (III) first, to be followed by Mn (IV). When this concept is applied to the observed morphology inside the prisms, it has to be concluded that oxidation proceeds from the larger voids, when these are filled with air whereas the prisms themselves are still partly saturated with water. This mechanism, however, proceeding only in a part of the interior of peds, is characteristic for gley, and not for pseudogley processes. The occurrence of clearly developed mangans on faces of prisms, points into the same direction. The profile therefore shows the morphology of a strongly developed pseudogley, tending to a stagnogley (Mückenhausen, 1962).

\section{The classification}

As discussed in the previous section, the profile may be classified as a StagnogleyPseudogley (Mückenhausen, 1962) (Subtyp). According to the USDA Classification System, 7th Approximation (1960 and supplement 1967), the profile is classified as an Aeric Glossaqualf: clay skins were not present and could therefore not be observed in the field. Micromorphological analysis, however, revealed the presence of much oriented clay in the $B_{2 \mathrm{tg}}$. The pedon had an ochric epipedon and the albic horizon was clearly tonguing into the argillic. This was proved by the separate analysis of the material of the tongues, and by the observation of well developed skeletans on ped faces. Finally an analysis of colours in the several horizons lead to the reported classification. 

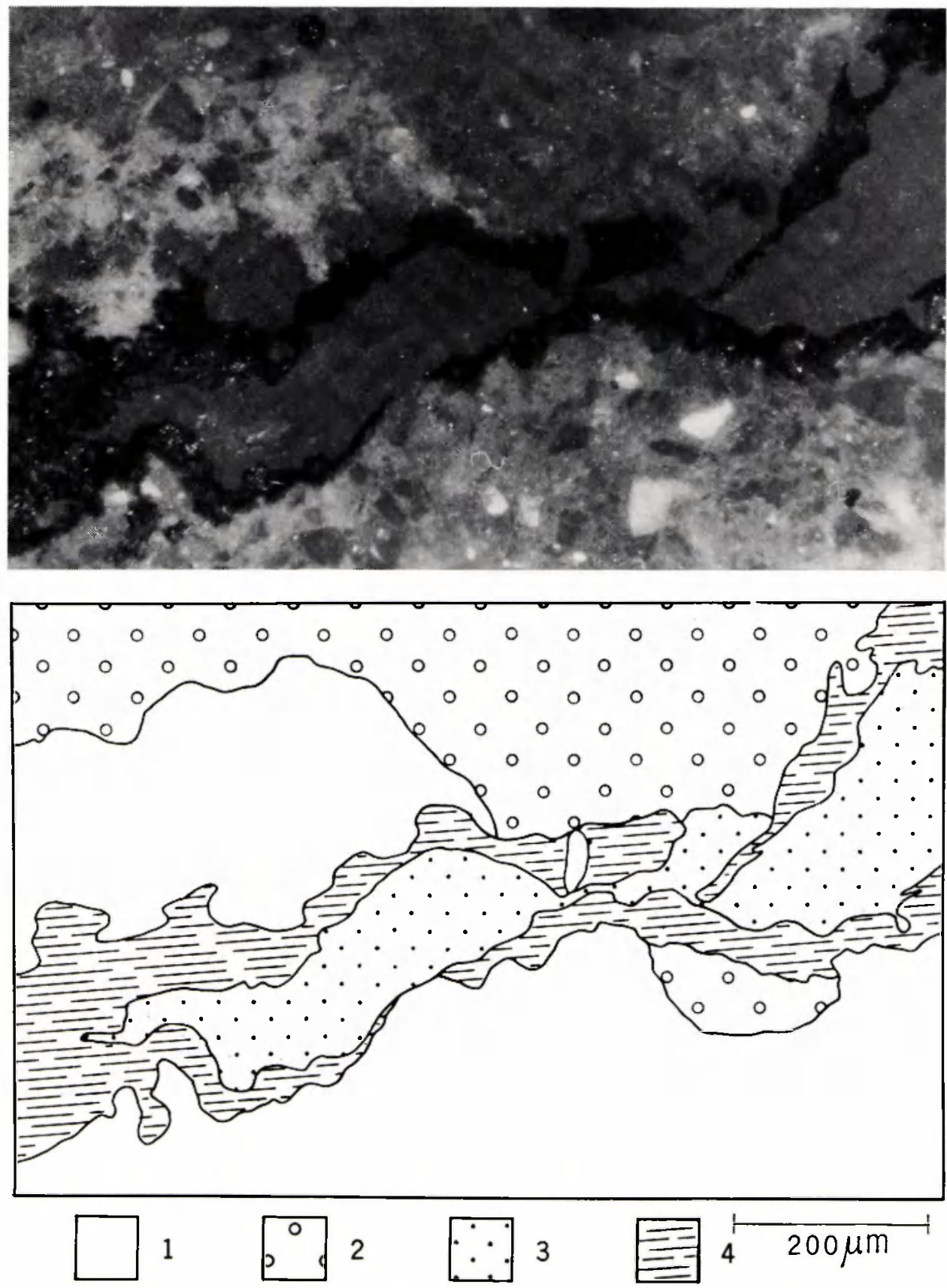

Fig. 3 A neomangan along a channel inside a prism (picture with incident $\mathrm{Hg}$-light); $\mathrm{I}=\mathrm{s}$-matrix, with a relatively high content of iron (light colour); $2=s$-matrix with a relatively' low content of iron (darker colour) ; $3=$ channel; $4=$ channel neomangan 


\section{References}

Blume, H. P., 1968. Zum Mechanismus der Marmorierung und Konkretionsbildung in Stauwasserböden. Z. PflErnähr. Düng. Bodenk. 119: 124-133.

Bouma, J., Pons, L. J. \& Schuylenborgh, J. van, 1968. On soil formation in temperate humid climate. VI. The formation of a glossudalf in loess (silt-loam). Neth. J. agric. Sci. 16: 58-71.

Brewer, R., 1964. Fabric and mineral analysis of soils. Wiley, New York, pp. 470.

Burri, C., 1964. Petrochemical calculation based on equivalents. Jerusalem, translated from German.

Gile, L. H. \& Grossman, R. B., 1968. Morphology of the argillic horizon in desert soils of Southern New Mexico. Soil Sci. 106: 6-15.

Hallsworth, E. G., 1963. An examination of some factors affecting the movement of clay in an artificial soil. J. Soil Sci. 14: 360-371.

Hoeksema, K. J. \& Edelman, C. H., 1960. The role of biological homogenization in the formation and transformation of grey-brown podzolic soils. Proc. 7th Int. Congr. Soil Sci. (Madison, Wisc.), Vol. IV, p. 402-405.

Hole, F. D., 1961. A classification of pedoturbations and some other processes and factors of soil formation in relation to isotropism and anisotropism. Soil Sci. 19: 375-377.

Janekovic, G., 1961. Über das Alter und den Bildungsprozess von Pseudogley aus pleistozänen Staublehm am südwestlichen Rande des pannonischen Beckens. Mitteilungen der österreichischen Bodenkundlichen Gesellschaft, Heft 6, pp. 184-189.

Jha, P. P. \& Cline, M. G., 1963. Morphology and genesis of a sol brun acide with fragipan in uniform silty material. Proc. Soil Sci. Soc. Am. 27: 339-344.

McCaleb, S. B., 1959. The genesis of the Red-Yellow Podzolic Soils. Proc. Soil Sci. Soc. Am. 23: 164-168.

Mückenhausen, E., 1962. Entstehung, Eigenschaften und Systematik der Böden der Bundesrepublik Deutsland. DLG-Verlag, Frankfurt.

Plas, L. van der \& Schuylenborgh, J. van, 1970. Petrochemical calculations applied to soils (with special reference to soil formation). Geoderma (in press).

Soil Survey Staff, 1951. Soil Survey Manual, with supplement, 1962.

Soil Survey Staff, 1960. Soil Classification, 7th Approximation, with supplement, 1967. 